\title{
Identifikasi Karakteristik Pelanggan: Pengembangan Persona Pelanggan Layanan Penanganan Gangguan Indihome PT Telkom Witel Surabaya Selatan
}

\author{
Ni Putu Cista Deviutami Sukma, Imam Baihaqi, dan Berto Mulia Wibawa \\ Departemen Manajemen Bisnis, Institut Teknologi Sepuluh Nopember (ITS) \\ e-mail: ibaihaqi@mb.its.ac.id
}

\begin{abstract}
Abstrak-Fenomena pertumbuhan daya konsumsi masyarakat Indonesia akan akses internet berdampak pada meningkatnya persaingan dalam industri penyelenggara akses internet. Sehingga perusahaan dalam industri ini harus dapat menciptakan nilai tambah dengan menyesuaikan layanan dengan ekspektasi pelanggan. Karakteristik pelanggan ini membuat customer experience menjadi hal yang krusial untuk diterapkan terutama dalam layanan back end yaitu layanan penanganan gangguan yang berfungsi untuk menjaga kualitas layanan internet yang stabil. PT Telekomunikasi Indonesia merupakan salah satu perusahaan milik negara yang menyediakan layanan akses internet. Penelitian ini bertujuan untuk mengidentifikasi karakteristik pelanggan terhadap layanan penanganan gangguan pada PT Telkom Witel Surabaya Selatan. Identifikasi karakteristik pelanggan dilakukan melalui wawancara mendalam kepada 12 pelanggan individual yang dibedakan berdasarkan tipe rumah yaitu residensial, apartemen, dan premium cluster. Pembagian ini ditujukan untuk eksplorasi karakteristik tiap pelanggan berdasarkan perbedaan tipe pelanggan melalui pengembangan persona. Hasil analisis menunjukkan adanya perbedaan signifikan antara karakteristik, kebutuhan, ekspektasi serta penilaian layanan dari masing-masing tipe pelanggan terhadap layanan penanganan gangguan. Penelitian ini berkontribusi dalam memberikan wawasan terkait perbedaan karakteristik pelanggan berdasarkan tipe rumah di PT Telkom Witel Surabaya Selatan.
\end{abstract}

Kata Kunci-Customer Experience, Karakteristik Pelanggan, Layanan Penanganan Gangguan, PT Telkom Witel Surabaya Selatan

\section{PENDAHULUAN}

$I^{\prime}$ NTERNET merupakan salah satu kebutuhan utama bagi masyarakat Indonesia seiring dengan berkembangnya daya konsumsi masyarakat [1]. Perkembangan kebutuhan akses internet masyarakat Indonesia hingga tahun 2018 terus meningkat hingga mencapai 10,12 persen dan mengakibatkan meningkatnya persaingan antar perusahaan baik perusahaan besar dan kecil dalam industri penyelenggara akses internet di Indonesia [2]. Persaingan ini muncul karena konsumen individual memiliki tendensi untuk berganti-ganti layanan internet dari berbagai perusahaan penyedia karena adanya banyak pilihan namun memiliki diferensiasi yang rendah antar pilihan tersebut. Sehingga kualitas layanan akses internet menjadi hal yang krusial bagi perusahaan dalam usahanya memenuhi ekspektasi pelanggan.

Salah satu karakteristik pelanggan dalam menggunakan layanan internet adalah sensitif terhadap kualitas dari layanan yang didapatkan. Pandangan pelanggan terhadap kualitas dari layanan terutama layanan yang disediakan perusahaan penyedia akses internet dipengaruhi oleh aspek pribadi, sosial maupun psikologis pelanggan. Sehingga perusahaan perlu mengetahui perbedaan segmen pelanggan individual berdasarkan salah satu aspek tersebut guna menyesuaikan layanan dengan karakteristik pelanggan [3].

Dalam menjaga kualitas layanan, perusahaan dalam industri penyelenggara akses internet menetapkan standar level kualitas dalam hal kecepatan dan kesesuaian fitur layanan yang dapat disediakan perusahaan kepada pelanggan atau disebut juga Service Level Agreement (SLA). Layanan back end yaitu layanan penanganan gangguan kemudian disediakan perusahaan agar dapat menjaga kualitas layanan sesuai standar SLA. Namun, perusahaan dalam industri ini umumnya hanya fokus pada peningkatan variasi layanan front end atau komersialiasi dari layanan internet dan varian layanan lainnya tanpa memperhatikan layanan pendukung. Hal ini menyebabkan kegagalan perusahaan dalam memahami dan menyesuaikan layanan dengan kebutuhan pelanggan serta dalam hal mengatur proses layanan yang melibatkan sumber daya perusahaan [4]. Sehingga dibutuhkan evaluasi desain proses bisnis untuk menghindari kegagalan perusahaan dalam menyesuaikan layanan berdasarkan kebutuhan pelanggan dan kapabilitas perusahaan.

Dalam merancang pengembangan layanan penanganan gangguan yang tepat, perusahaan penyedia akses internet memerlukan pemahaman pada sudut pandang pelanggan sehingga dapat memberikan pengalaman yang baik kepada pelanggan. Dengan menyesuaikan layanan berdasarkan sudut pandang pelanggan maka perusahaan dapat meningkatkan pangsa pasar dari produk yang ditawarkan serta mengurangi keinginan pelanggan untuk berhenti berlangganan dan pindah ke penyedia layanan lainnya. PT Telkom Witel Surabaya Selatan merupakan salah satu perusahaan penyedia layanan akses internet dengan daerah operasional Surabaya bagian selatan yang memerlukan pengembangan layanan untuk produk Indihome guna mendukung kebutuhan pelanggan terhadap layanan internet yang berkualitas. Pangsa pasar pelanggan 
segmen retail yang dimiliki oleh PT Telkom Witel Surabaya Selatan mengalami penurunan di tahun 2019 dibandingkan tahun sebelumnya dikarenakan jumlah pelanggan yang berhenti layanan lebih banyak daripada pelanggan baru. Terdapat beberapa alasan pelanggan memutuskan untuk berhenti berlangganan, salah satunya adalah ketidakpuasan terhadap layanan penanganan gangguan yang dianggap tidak memenuhi ekspektasi pelanggan dalam hal memberikan layanan internet berkualitas kepada pelanggan [5].

Ketidakpuasan pelanggan terhadap layanan penanganan gangguan ini merupakan dampak dari kegagalan dalam menyesuaikan layanan dengan kebutuhan pelanggan. Hal ini mengarah pada urgensi dalam pengaplikasian fokus customer experience dalam pengembangan layanan. Penelitian terdahulu menjelaskan bahwa dengan menerapkan konsep customer experience maka perusahaan dapat mengatur pengalaman pelanggan selama menggunakan layanan perusahaan secara strategis sehingga dapat meningkatkan kepuasan pelanggan serta memenuhi kebutuhan dan ekspektasi pelanggan terhadap layanan yang didapatkan [6][7]. Penelitian ini penting untuk dilakukan melihat peningkatan persaingan dalam industri penyelenggara akses internet yang mendorong perusahaan didalamnya untuk dapat menyediakan layanan yang berkualitas kepada pelanggan sebagai nilai tambah untuk meningkatkan daya saingnya. Namun kondisi dari layanan yang disediakan PT Telkom Witel Surabaya Selatan terutama layanan penanganan gangguan masih dinyatakan kurang memuaskan oleh pelanggan karena belum dapat memenuhi kebutuhan dan ekspektasi mereka. Oleh sebab itu, penelitian ini hadir untuk mengidentifikasi karakteristik pelanggan yang meliputi kebutuhan dan ekspektasi terhadap layanan penanganan gangguan serta karakteristik pelanggan yang harus diperhatikan PT Telkom Witel Surabaya Selatan melalui pengembangan pemetaan pelanggan berdasarkan karakteristik yang dibedakan berdasarkan aspek sosial yaitu keadaaan ekonomi yang dilihat dari tipe rumah yaitu tipe residensial, apartemen, dan perumahan mewah menggunakan kerangka Persona.

\section{LANDASAN TEORI}

\section{A. Pemasaran Layanan}

Pemasaran layanan merupakan proses penawaran layanan hingga aktivitas tersebut selesai digunakan dimana keputusan pelanggan untuk menggunakan layanan oleh pelanggan didasari atas dasar kebutuhan dan ekspektasi pelanggan yang mengarah pada kepuasan pelanggan terhadap layanan yang didapatkan. Proses ini berfokus pada kesesuaian nilai yang diciptakan dari penggunaan layanan dengan apa yang dibutuhkan dan diharapkan pelanggan [8][9].

\section{B. Industri Penyelenggara Layanan Akses Internet}

Industri penyelenggara layanan akses internet merupakan industri yang memiliki tujuan utama bisnis untuk memenuhi kebutuhan pelanggan dalam akses internet serta menciptakan hubungan antara konsumen tingkat akhir yang merupakan individu maupun organisasi pada jaringan internet publik dengan layanan akses internet sebagai produk utama yang ditawarkan [10]. Secara umum layanan dalam industri ini memiliki risiko yang tinggi dalam menjaga kualitas layanan yang disediakan kepada pelanggan. Hal ini menyebabkan perusahaan dalam industri ini menyediakan layanan back end yaitu layanan penanganan gangguan yang bertujuan untuk mendukung dan merawat stabilitas dari kualitas layanan akses internet. Pentingnya layanan penanganan gangguan adalah dalam hal menjaga hubungan baik dengan pelanggan. Hal ini dikarenakan layanan penanganan gangguan ditujukan untuk memberikan solusi atas disrupsi yang dialami pelanggan selama penggunaan layanan internet. Dari penanganan yang dilakukan perusahaan, pelanggan dapat memberikan respons positif maupun negatif yang kemudian berdampak pada hubungan pelanggan dengan perusahaan [11].

\section{Customer Experience}

Customer experience merupakan penggambaran dari apa yang dirasakan pelanggan selama menggunakan layanan perusahaan baik secara emosional, sensoris, kognitif, pragmatis, relasional, dan gaya hidup dari pelanggan tersebut [12]. Customer experience menjadi hal yang krusial bagi suatu perusahaan karena memiliki dampak pada kepuasan pelanggan dan hubungan pelanggan dengan perusahaan.

Penerapan konsep customer experience dapat diaplikasikan dalam evaluasi hingga perancangan perbaikan proses dari layanan maupun penyediaan produk karena memiliki dampak positif pada perusahaan. Secara emosional, dengan menerapkan customer experience maka dapat meningkatkan kepuasan pelanggan terhadap layanan dan loyalitas pelanggan [13]. Sedangkan secara fungsional, pengaplikasian customer experience dapat memberikan dampak sebagai berikut berdasarkan [14]: 1. Peningkatan pendapatan perusahaan dan efisiensi biaya operasional; 2. Peningkatan gross margin perusahaan dalam meningkatkan nilai tambah dengan tujuan meningkatkan aspek kompetitif perusahaan; 3. Peningkatan kepuasan karyawan; 4. Penyederhanaan proses bisnis.

\section{Persona}

Persona merupakan model yang menggambarkan pola perilaku pelanggan dalam menggunakan produk maupun layanan [15]. Pendekatan melalui pemetaan persona dapat memberikan perusahaan gambaran dalam mengidentifikasi perilaku serta tujuan dari pelanggan selama berhubungan dengan produk yang dimiliki perusahaan [16]. Selain itu, pendekatan melalui persona dapat memberikan perusahaan perspektif baru dari sisi pelanggan dalam mengembangkan produk maupun layanan agar sesuai dengan ekspektasi dari target pelanggan. Persona dipetakan berdasarkan profil pelanggan, demografi, kebutuhan, perilaku, tujuan serta pengalaman pelanggan sebelumnya dalam menggunakan produk maupun layanan. Kerangka yang digunakan berdasarkan kerangka Oracle (2018) pada Gambar 1. Kerangka persona ini terdiri dari sembilan komponen yang dapat menggambarkan karakteristik dari seorang individu secara deskriptif. Sembilan komponen tersebut terdiri dari: 1 . Lifestyle, Interest \& Personality yang menggambarkan gaya hidup, minat, dan kebiasaan pelanggan persona; 2. 


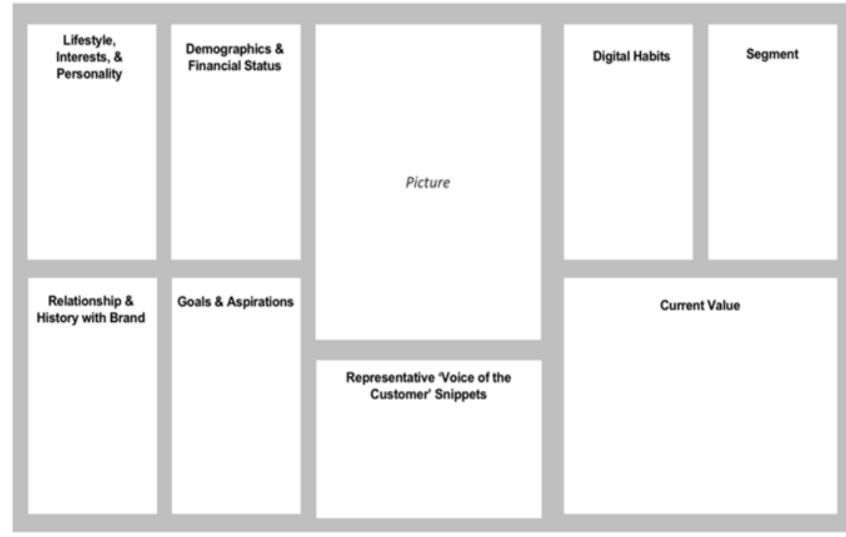

Gambar 2. Kerangka Persona

Demographic \& Financial Status untuk menjelaskan status persona secara demografis terkait usia, lokasi, dan pekerjaan serta kondisi finansial persona; 3. Relationship \& History with Brand untuk menjelaskan hubungan antara persona dengan penyedia layanan dan bagaimana pengalaman persona selama menggunakan layanan tersebut; 4. Goals \& Aspirations untuk menjelaskan tujuan dari persona dalam menggunakan layanan; 5. Profile Picture untuk menggambarkan persona secara fisik; 6. Digital Habits memberikan gambaran pada kebiasan persona dalam menggunakan teknologi digital terutama layanan internet dalam aspek ketergantungan persona terhadap pemakaian internet serta frekuensi pemakaian; 7. Segment memberikan penjelasan mengenai kategorisasi persona dalam segmentasi penyedia layanan; 8. Current Value menjelaskan nilai yang diberikan persona terhadap layanan yang ia dapatkan; 9. Representative "Voice of the Customer" Snippets menjelaskan bagaimana persona dalam menggunakan layanan.

Dalam pengumpulan data untuk memetakan persona didapatkan melalui metode akses langsung yaitu wawancara dan observasi dengan tujuan untuk mengembangkan layanan dengan tepat sesuai dengan kebutuhan dan ekspektasi pelanggan. Berikut merupakan penjelasan mengenai wawancara dan observasi:

\section{1) Observasi}

Observasi dilakukan untuk memberikan pemahaman secara komprehensif terhadap proses serta pemahaman terhadap keseluruhan perilaku dan sikap yang disadari maupun tidak disadari pelanggan melalui fokus pada bahasa tubuh, emosi, dan reaksi selama melakukan proses [7][16].

2) Wawancara

Wawancara merupakan pendekatan yang lebih difokuskan pada pengumpulan informasi secara spesifik dari pelanggan secara langsung agar mendapatkan pemahaman yang lebih jelas terhadap pengalaman pelanggan melalui cara pelanggan dalam mengekspresikan idenya [7].

\section{METODE PENELITIAN}

\section{A. Objek dan Subjek Penelitian}

Objek amatan dalam penelitian ini adalah PT Telkom Witel Surabaya Selatan. Pemilihan objek ini didasarkan pada

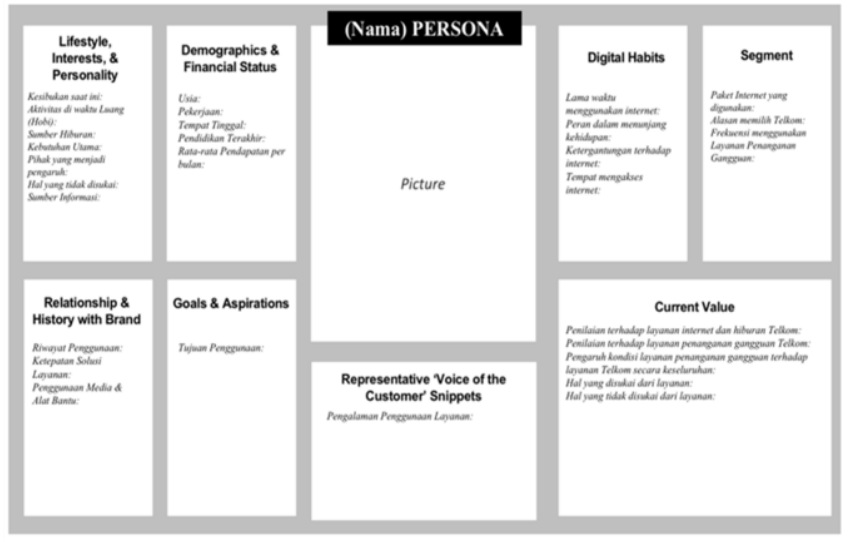

Gambar 2. Kerangka Persona

Tabel 1.

Kesediaan Pelanggan menjadi Responden Penelitian

\begin{tabular}{ccc}
\hline \hline Rentang Umur & Bersedia & Tidak Bersedia \\
\hline $21-27$ tahun & 5 & 10 \\
$28-34$ tahun & 1 & 2 \\
35 tahun ke atas & 6 & 9 \\
\hline Total & \multicolumn{3}{r}{} \\
\hline \hline
\end{tabular}

kebutuhan objek dalam hal pengembangan layanan yang sesuai dengan segmen pelanggan terutama dalam layanan penanganan gangguan yang merupakan layanan dengan nilai kepuasan pelanggan paling rendah. Sedangkan subjek penelitian yang digunakan adalah pelanggan Indihome yang perbah menggunakan layanan penanganan gangguan di PT Telkom Witel Surabaya Selatan.

\section{B. Desain Penelitian}

Penelitian ini menggunakan desain penelitian deskriptif dengan pendekatan kualitatif yang bertujuan untuk mendeskripsikan karakteristik dari sekelompok individu dalam kategori yang berbeda terhadap suatu aktivitas [17]. Data yang dibutuhkan merupakan data primer mengenai demografi dan pandangan pelanggan terhadap layanan yang diteliti.

\section{Pengumpulan Data}

Pengumpulan data pada penelitian ini dilakukan melalui wawancara mendalam yang dilakukan pada pelanggan Indihome yang pernah menggunakan layanan penanganan gangguan di PT Telkom Witel Surabaya Selatan. Wawancara dipilih untuk mengetahui perbedaan karakteristik antar pelanggan yang dibagi berdasarkan segmen pelanggan individual (retail customer). Wawancara mengambil sampel 12 pelanggan yang akan dibagi perusahaan dan dibagi menjadi 3 tipe pelanggan yaitu masing-masing 4 pelanggan untuk segmen pelanggan residensial, apartemen, dan perumahan mewah.

\section{Analisis Data}

Analisis data dilakukan setelah melakukan pemetaan hasil wawancara dalam kerangka persona yang mengacu pada Oracle (2018). Hasil wawancara yang telah didapatkan berdasarkan pedoman wawancara dapat dipetakan berdasarkan komponen dalam kerangka persona dimana setiap komponen dapat merepresentasikan masing-masing karakteristik sosial 


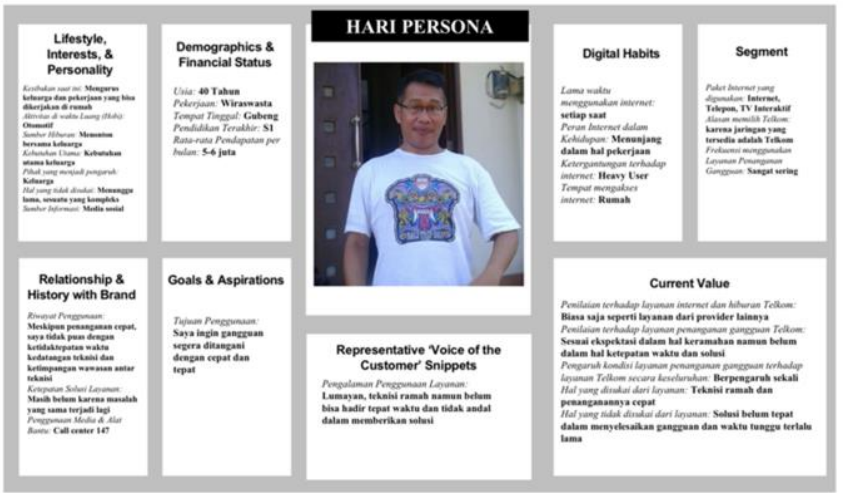

Gambar 5. Kerangka Persona Profil Fiksi "Hari"

berdasarkan tipe rumah pelanggan. Pedoman pertanyaan dalam wawancara terdapat pada Gambar 2.

\section{ANALISIS DAN DISKUSI}

\section{A. Pengolahan Data}

Wawancara mendalam dilakukan kepada 12 responden dengan persebaran 4 pelanggan segmen residensial, 4 pelanggan segmen apartemen, dan 4 pelanggan segmen perumahan mewah. Responden yang didapatkan berada pada tiga rentang umur yaitu rentang umur $21-27$ tahun, $28-34$ tahun, dan 35 tahun keatas yang didapatkan dari hasil observasi di lapangan terkait kesediaan pelanggan menjadi responden. Dari 33 pelanggan yang ditanyai kesediannya pada Tabel 1, terdapat 21 pelanggan yang tidak bersedia menjadi responden. Hal ini diakibatkan dari kurangnya pengetahuan mengenai layanan penanganan gangguan Indihome, tidak memiliki waktu untuk melakukan wawancara serta memang tidak bersedia untuk melakukan wawancara.

\section{B. Analisis Persona}

Berdasarkan hasil wawancara yang telah dipetakan dalam kerangka persona didapatkan 12 kerangka persona yang menggambarkan karakteristik masing-masing pelanggan. Kemudian 4 kerangka persona pelanggan segmen residensial diolah dengan mengambil data mayoritas dari setiap komponen untuk mendapatkan profil fiksi "Hari" yang mewakili karakteristik pelanggan residensial PT Telkom Witel Surabaya Selatan pada Gambar 3.

Profil fiksi "Hari" merupakan seorang wiraswasta berumur 40 tahun yang memiliki kesibukan dalam mengurus pekerjaan serta keluarga secara sekaligus. Hari termasuk dalam kategori heavy user dalam penggunaan layanan internet dengan tujuan menunjang pekerjaaannya serta untuk mendukung kebutuhan keluarganya dalam menggunakan akses internet. Hari memilih menggunakan Indihome karena layanan Indihome memiliki jaringan yang tersedia di area rumahnya sehingga akses pemasangan dapat dilakukan dengan lebih mudah. Namun dalam pemakaiannya, Hari sering mengalami gangguan yang mengganggu penggunaan akses internet untuk dirinya serta keluarganya. Sehingga ia sangat bergantung pada layanan penanganan gangguan yang dapat menyelesaikan gangguan tersebut dengan penanganan yang cepat dan solusi yang tepat.

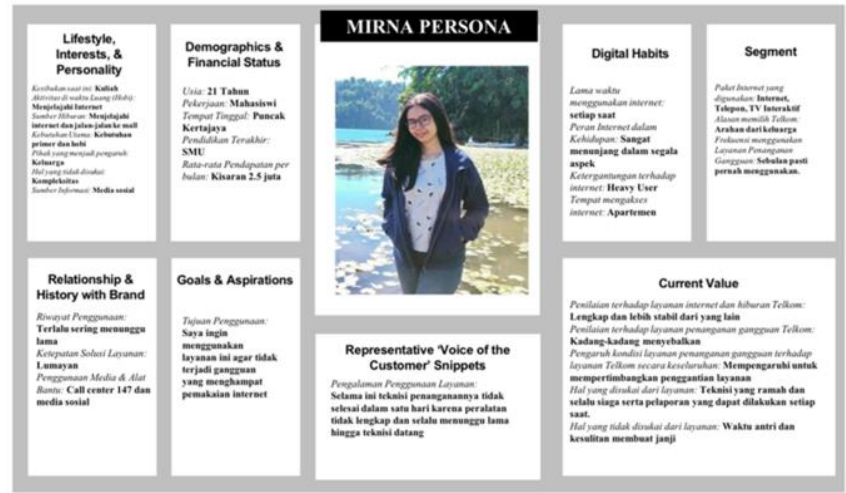

Gambar 5. Kerangka Persona Profil Fiksi "Mirna"

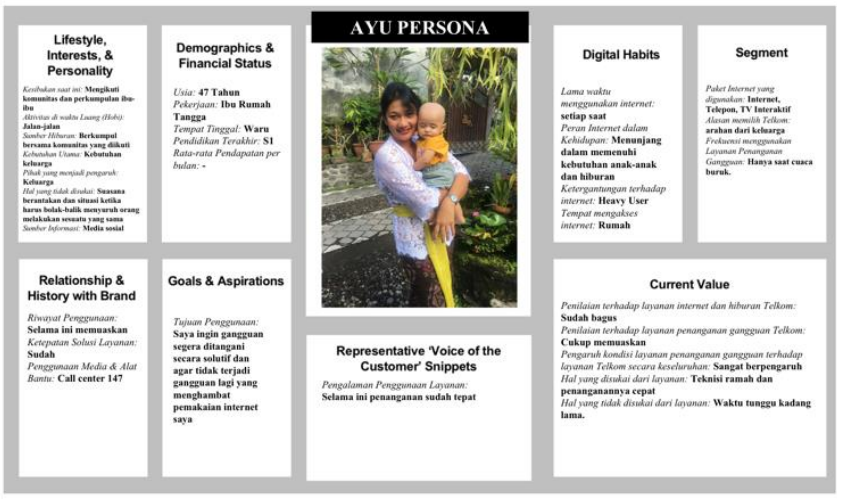

Gambar 3. Kerangka Persona Profil Fiksi "Ayu"

Berdasarkan pengalamannya, Hari merasa teknisi memiliki sikap yang ramah selama proses penanganan namun belum bisa memenuhi ekspektasi Hari dalam hal kecepatan proses penanganan serta ketepatan solusi penanganan yang diberikan untuk gangguan yang terjadi.

Berdasarkan wawancara, profil fiksi "Hari" memperlihatkan karakteristik yang menyukai sesuatu yang praktis dan cepat sehingga ia menginginkan layanan penanganan gangguan yang dapat tersedia setiap saat ia membutuhkannya. Hari rela menunggu selama maksimal 24 jam untuk mendapatkan layanan penanganan gangguan atas akses internetnya dikarenakan ia memiliki mobilitas yang tinggi dan kegiatan yang harus diselesaikan dengan internet. Profil fiksi "Hari" juga memiliki karakteristik berhati-hati dalam menerima suatu hal baru. Hal ini digambarkan melalui kebutuhannya terhadap detail pada proses layanan yang telah ia lalui melalui media komunikasi maupun aplikasi. Dari penjelasan karakteristik ini dapat dilihat bahwa Hari lebih mementingkan kecepatan dan kejelasan selama proses layanan penanganan gangguan.

Selain penilaian Hari terhadap layanan penanganan gangguan, juga diidentifikasi kebutuhan yang muncul selama pengalaman Hari menggunakan layanan. Kebutuhan utamanya adalah dalam hal penyebaran informasi yang lebih jelas melalui media komunikasi perusahaan, pengembangan fitur tracking proses layanan pada aplikasi, serta peningkatan kualitas teknisi. Hingga saat ini, Hari memiliki ekspektasi yang rendah terhadap pihak Telkom karena dianggap hanya terfokus pada komersialisasi layanan baru tanpa mempertimbangkan layanan pendukung untuk perawatan setiap layanan baru tersebut. 
Penilaian ini berdampak pada pertimbangan Hari untuk menggunakan layanan kompetitor.

Kemudian untuk 4 profil persona pelanggan segmen apartemen diambil data mayoritas dari setiap komponen kerangka persona untuk mendapatkan kerangka persona profil fiksi "Mirna" yang mewakili karakteristik pelanggan apartemen pada Gambar 4.

Profil fiksi "Mirna" adalah seorang mahasiswi berumur 21 tahun yang telah menginjak tahun ketiga pada perkuliahannya. Mirna termasuk dalam kategori heavy user dalam menggunakan layanan internet untuk menunjang seluruh aspek dalam hidupnya terutama hiburan dan tugas. Mirna memilih untuk menggunakan layanan Indihome karena adanya pengaruh dari keluarganya. Selama menggunakan layanan Indihome, Mirna mendapat gangguan setidaknya satu kali setiap satu bulan. Mirna merasa hal ini merupakan disrupsi dalam kegiatannya menggunakan internet sehingga ia sangat membutuhkan layanan penanganan gangguan untuk mengatasi gangguan yang ia alami. Berdasarkan pengalamannya, Mirna merasa teknisi sering tidak siap dalam menangani gangguan karena gagal memberikan solusi yang tepat serta tidak membawa peralatan yang tepat sehingga proses penanganan berlangsung lama.

Berdasarkan wawancara, profil fiksi "Mirna" memperlihatkan karakteristik yang sensitif terhadap detail dan penjelasan atas suatu hal. Karakteristik ini terlihat dari keinginannya untuk mengetahui alasan hingga risiko dari penerapan solusi penanganan dari teknisi dalam mengatasi gangguannya. Selain itu, ia juga mementingkan kecepatan dalam penanganan karena ia tidak bisa melanjutkan kegiatannya tanpa adanya akses internet. Dari penjelasan karakteristik ini dapat dilihat bahwa Mirna lebih mementingkan kelengkapan detail serta kecepatan selama proses penanganan gangguan.

Selain itu, analisis juga difokuskan pada kebutuhan Mirna yang belum dipenuhi oleh perusahaan seperti dalam hal pengembangan teknologi pada aplikasi agar lebih praktis dan mudah digunakan serta pengembangan kemampuan dari setiap teknisi dalam hal kelengkapan perlengkapan hingga pemberian detail penjelasan kepada pelanggan. Hingga saat ini, Mirna memiliki ekspektasi yang cukup baik terhadap layanan penanganan gangguan Indihome. Mirna merasa perusahaan telah memberikan layanan yang baik selama ini dan hanya perlu melakukan optimalisasi pada beberapa aspek.

Sedangkan untuk 4 profil persona segmen perumahan mewah digabungkan juga menjadi satu profil fiksi dengan mengambil data mayoritas dari setiap komponen kerangka persona. Karakteristik pelanggan perumahan mewah diwakili oleh profil fiksi "Ayu" pada Gambar 5.

Profil fiksi "Ayu" merupakan seorang ibu rumah tangga berumur 47 tahun yang aktif dalam mengikuti komunitas di lingkungan ia tinggal. Ayu merupakan heavy user dalam hal penggunaan akses internet terutama dalam mendapatkan informasi terbaru, sumber hiburan, dan melakukan komunikasi dengan relasinya. Ayu memilih layanan Indihome karena adanya pengaruh dari keluarganya. Selama menggunakan layanan Indihome, Ayu mengaku jarang mendapatkan gangguan kecuali jika kondisi cuaca sedang buruk. Hal ini menyebabkan Ayu tidak terlalu bergantung pada layanan penanganan gangguan Indihome. Selama ini juga, Ayu merasa puas dalam menggunakan layanan penanganan Indihome karena dapat memberikan solusi terhadap gangguan yang terjadi.

Berdasarkan wawancara, profil fiksi "Ayu" memperlihatkan karakteristik pelanggan yang menyukai penanganan personal dan senang menyebarkan informasi pada komunitas yang ia ikuti. Penanganan personal telah dipenuhi oleh perusahaan melalui pembagian teknisi untuk setiap pelanggan di perumahan mewah. Kemudian, dengan karakteristik sumber penyebaran informasi menyebabkan segmen pelanggan perumahan mewah dapat menjadi media word of mouth yang baik terkait dengan layanan yang ia dapatkan dari perusahaan dan dapat berdampak pada pandangan lingkungan komunitasnya kepada layanan Indihome secara keseluruhan. Sehingga dapat disimpulkan bahwa Ayu memiliki karakteristik menyukai personalisasi serta merupakan sosok influencer dalam suatu komunitas.

Selain itu juga diidentifikasi kebutuhan Ayu yang perlu dipenuhi oleh Telkom terkait pengembangan layanan penanganan gangguan Indihome seperti peningkatan kualitas teknisi serta customer service dalam menjelaskan solusi, pengembangan fitur aplikasi serta komersialisasi aplikasi melalui infografis pada media sosial Telkom. Hingga saat ini, Ayu memiliki ekspektasi tinggi terhadap layanan penanganan gangguan serta layanan Indihome secara keseluruhan dan memiliki keyakinan bahwa perusahaan dapat meningkatkan kualitas dari layanan penanganan gangguan.

Dari hasil analisis persona dapat diketahui karakteristik pelanggan dalam hal kebutuhan dan ekspektasi pelanggan serta penilaian yang dipengaruhi oleh pengalaman pelanggan berdasarkan aspek sosial yaitu melalui perbedaan tipe rumah pelanggan. Karakter pelanggan yang diidentifikasi adalah: 1 . Pelanggan segmen residensial memiliki karakteristik sensitif terhadap waktu tunggu serta kejelasan dari proses yang ia lewati; 2. Pelanggan segmen apartemen memiliki karakteristik yang lebih mementingkan kelengkapan detail dan kecepatan penyelesaian; 3. Pelanggan segmen perumahan mewah memiliki karakteristik yang menyukai personalisasi serta sosok influencer dalam suatu komunitas.

Selain itu, dapat dilihat bahwa pelanggan segmen residensial memiliki penilaian yang kurang baik terhadap layanan penanganan gangguan Indihome PT Telkom Witel Surabaya Selatan. Sehingga diperlukan fokus lebih pada perbaikan layanan dan pemenuhan kebutuhan pelanggan dalam segmen ini agar dapat mempertahankan pangsa pasar Indihome. Hasil identifikasi karakteristik pelanggan dari segi sosial yang dilihat dari tipe rumah ini dapat diaplikasikan pada PT Telkom Witel Surabaya Selatan untuk menambah perspektif baru dalam menyelesaikan permasalahan terkait pengembangan layanan serta dalam memberikan inovasi pada proses dan desain layanan yang dapat memberikan pengalaman baik bagi pelanggan. Dengan memperhatikan karakteristik setiap segmen pelanggan maka perusahaan dapat mengembangkan layanan yang lebih sesuai dengan pelanggan sehingga dapat berdampak 
pada kepuasan pelanggan serta meningkatkan daya saing agar dapat bertahan dalam ketatnya persaingan dalam industri penyelenggara akses internet [18].

\section{KESIMPULAN DAN SARAN}

\section{A. Kesimpulan}

Berdasarkan hasil analisis yang telah dilakukan pada bab sebelumnya terdapat beberapa hal yang dapat disimpulkan pada penelitian ini.

1) Terdapat perbedaan karakteristik diantara segmen pelanggan berdasarkan aspek sosial yang dilihat dari tipe rumah pelanggan. Perbedaan karakteristik antar pelanggan ini dapat menjadi dasar dalam merancang perbaikan layanan penanganan gangguan di PT Telkom Witel Surabaya Selatan. Melalui pemahaman terhadap identifikasi karakteristik antar segmen pelanggan ini dapat memberikan pengalaman yang sesuai kepada masing-masing pelanggannya.

2) Pelanggan segmen residensial merupakan tipe pelanggan yang perlu diperhatikan perusahaan karena mengalami ekspektasi yang rendah terhadap layanan penanganan gangguan serta tendensi yang lebih tinggi dalam berganti penyedia layanan.

\section{B. Keterbatasan dan Saran Penelitian}

Terdapat beberapa keterbatasan pada penelitian ini. Pertama, penelitian ini terbatas pada segmen pelanggan yang terbatas pada pelanggan individual. Keadaan tersebut menyebabkan perusahaan tidak dapat merepresentasikan seluruh segmen pelanggan terutama segmen pelanggan korporat dan bisnis. Kedua, penelitian ini hanya berfokus pada pembagian segmen dari segi sosial yaitu keadaan ekonomi yang dilihat dari tipe rumah.

Saran untuk penelitian selanjutnya didasarkan dari keterbatasan penelitian ini. Pertama, penelitian selanjutnya dapat menggunakan segmen pelanggan komunitas atau organisasi seperti pelanggan korporat maupun bisnis. Penelitian selanjutnya juga dapat menggunakan hasil wawancara terkait karakteristik pelanggan untuk melakukan analisis lebih lanjut terhadap akar masalah dari penilaian pengalaman pelanggan yang kurang baik. Kemudian, penelitian selanjutnya juga dapat mengaplikasikan pendekatan pemetaan persona untuk mengidentifikasi karakteristik dari jenis layanan dalam industri lain seperti industri perbankan.

\section{DAFTAR PUSTAKA}

[1] World Bank, "Indonesia's Middle Class Vital for the Country's Future," 2017. [Online]. Available: https://www.worldbank.org/en/news/pressrelease/2017/12/04/indonesia-middle-class-vital-for-the-country-future.

[2] APJII, "Penetrasi dan Profil Perilaku Pengguna Internet Indonesia," 2018.

[3] K. W. Astutik and Y. Afandi, "Pengaruh Faktor Sosial, Pribadi dan Psikologis terhadap Keputusan Pembelian Indihome di PT Telkom Indonesia Witel Jatim Selatan Malang," J. Apl. Bisnis, vol. 1, no. 1, pp. 81-90, 2016.

[4] K. James, "Encounter analysis: Front-line conversations and their role in improving customer service," Local Gov. Stud., vol. 15, no. 3, pp. 11-24, 1989.

[5] PT Telekomunikasi Indonesia Witel Surabaya Selatan, "Data Terminate (Churn APS) Witel Surabaya Selatan," 2019.

[6] M. M. Tseng, M. Qinhai, and C.-J. Su, "Mapping customers' service experience for operations improvement," Bus. Process Manag. J., vol. 5, no. 1 , pp. 50-64, 1999.

[7] J. Trischler and A. Zehrer, "Service design: Suggesting a qualitative multistep approach for analyzing and examining theme park experiences," J. Vacat. Mark., vol. 18, no. 1, pp. 57-71, 2012.

[8] C. Grönroos, "Service marketing. A study of the marketing function in service firms," Diss. Helsinki Stock. Hanken Swedish Sch. Econ. Mark. Tech. Cent. Akad. Helsinki, vol. 16, no. 7, pp. 30-41, 1979.

[9] C. Grönroos and A. Ravald, "Service as business logic: implications for value creation and marketing," J. Serv. Manag., vol. 22, no. 1, pp. 5-22, 2011.

[10] W. B. Norton, "Internet service providers and peering," in Proceedings of NANOG, 2001, vol. 19, pp. 1-17.

[11] J. S. Smith, P. F. Nagy, K. R. Karwan, and E. Ramirez, "The contingent nature of service recovery system structures," Int. J. Oper. Prod. Manag., vol. 32, no. 7, pp. 877-903, 2012.

[12] A. Følstad and K. Kvale, "Customer journeys: a systematic literature review," J. Serv. Theory Pract., vol. 28, no. 2, pp. 196-227, 2018.

[13] R. R. Klink, J. Q. Zhang, and G. A. Athaide, "Designing a Customer Experience Management Course," J. Mark. Educ., vol. 00, no. 0, pp. 1$13,2018$.

[14] McKinsey, "Customer Experience: Creating Value Through Transforming Customer Journeys," 2016.

[15] S. Blomkvist, "Persona-an overview," in Theoretical Perspectives in Human-Computer Interaction, 2002, vol. 22, pp. 1-8.

[16] E. Brangier and C. Bornet, Persona: A method to produce representations focused on consumers' needs, 1st ed. Boca Raton: CRC Press, 2011.

[17] V. A. Lambert and C. E. Lambert, "Qualitative descriptive research: An acceptable design," Pacific Rim Int. J. Nurs. Res., vol. 16, no. 4, pp. 255256, 2012.

[18] A. Y. Safitri, B. M. Wibawa, and D. S. Ardiantono, "Pengukuran Kepuasan dan Loyalitas Konsumen terhadap Kualitas Layanan Taksi Resmi Bandar Udara Juanda Surabaya," J. Sains dan Seni ITS, vol. 8, no. 1, pp. 1-7, 2019. 